\title{
Ethical concerns in Animal Cloning: Possible Risks and Assessment
}

\author{
Neha Sinha ${ }^{1}$, Sharvil Patil ${ }^{2}$, Udaya Kesigan ${ }^{3}$, T. Sai Chaitanya ${ }^{4}$, Simran Panigrahy ${ }^{5}$, \\ G.D. Tandon ${ }^{6}$ \\ 1,2,3,4,5 M.Tech. Integrated Biotechnology 4th year (VII Sem), Dr. D. Y. Patil Biotechnology and \\ Bioinformatics Institute Pune. \\ ${ }^{6}$ Faculty, Department of Bioetechnology, Dr. D. Y. Patil Biotechnology and Bioinformatics \\ Institute Pune.
}

Corresponding Author: G.D. Tandon

E-mail: g.tandon@dpu.edu.in

\begin{abstract}
The disciplines of biotechnology include various techniques that make use of biological systems or processes for the benefit of the human being. Living systems and organisms involved in biotechnology are used to develop, make, and modify products like antibiotics, vaccines, cloned animals, and the confectionery industry for their specific use. The science of ethics asks us to explain our actions and accounts for our objectives. Bioethics includes evaluation and use of ideas like right, wrong, evil and responsibility. It includes ethical issues arising from advancements in biology and medicine. It is related to many significant issues with respect to human, animal, food, and health. As we move from research to technology ethical questions emerge with respect to shielding human subjects and society from instability and misuse by researchers. The present study emphasizes the correlation of bioethical issues arising from animal cloning. The animal can be used for various purposes like reproductive and non-reproductive or therapeutics. Bioethics is used to minimize the harm done to living beings. The presumption is that all animals will avoid pain, distress, or death if given the choice, therefore it is ethical for humans to reduce exposing animals to these events. Circulation of information about the existing ethical considerations and other possibilities in animal experiments has two important roles; 1) it increases the awareness of the researchers for possible methods of using animals in the experiments, and 2) to ensure that the researchers are aware of the established alternatives.
\end{abstract}

Keywords: Biotechnology, bioethics, risk, bioethical issue, misuse, animal cloning.

\section{INTRODUCTION}

Biotechnology is a field of science that uses biological means to create products that benefit mankind. Techniques such as genetic engineering, cloning, r-DNA and other technologies which lead to the production of genetically modified products with enhanced characteristics. Though the applications of biotechnology are beneficial to mankind still, there is a possibility of some potential risks that might have some disastrous effect, therefore it becomes mandatory to follow the principles of "Bioethics" to avoid such disastrous events.

The word "Bioethics" is derived by merging two Greek words bios: life and ethike: ethics which deals with bioethical issues. It is a branch of ethical science that studies the [1] controversial ethical 
aspects such as philosophical, cultural, social, and legal issues arising in the fields of medical, biotechnological and other life sciences. It is a multi-disciplinary field that deals with ethical implications arise due to some practices in biological fields and helps in resolving them [2]. The concept of bioethics is commonly understood as a collective term for three broad fields viz. medical ethics, animal ethics, and environmental ethics. It is not a matter of local affairs that can be resolved by a local society, instead, they are worldwide issues having universal effects [2]. In general bioethics deals with subjects like 1) Human diagnostics 2) Agriculture 3) Synthetic biology 4) Patenting 5) Biotech and pharmaceutical companies 6) Gene Therapy 7) Stem cell research 8) Clinical Trials 9) Environment 10) Animal cloning etc. The important ones closely related to the present article are discussed as follows:

- Gene Therapy: It is the technique used to rectify some of the defective genes by manipulating the expression of certain genes for treating a disease. However various side effects like leukemia and even death have been observed.

- Stem cell therapy: Stem cells have an ability to differentiate into many different types of cells. Stem cell therapy is a new field of medical science that uses stem cells for the regeneration of dead cells or for generating organs for organ transplantation. [3]

- Clinical Trials: These are clinical studies taken upon animals or human beings for analysing medical, surgical, or behavioural interventions. It is the way to find out whether a new treatment such as new drugs, a new diet or a new medical device is going to be safe and effective or have some harmful side effects.

- Environmental ethics: It is the branch of applied ethics that deals with the study of moral values of human being towards the environment. [4]

- Animal cloning: Animal cloning is the process of creating a genetically identical replica of a cell or an organism [5]. Further details, particularly about animal cloning, are discussed later in this article.

\section{History of bioethics}

During the seventies, people considered that the term "Bioethics" was coined by an American Biochemist Van Rensselaer Potter. In his article, he linked Mankind, nature, culture, science, and values [6]. He had a prominent role in the formation of today's Bioethics which led to the development of new discipline to address the ethical issues raised in the field of medical and life sciences. But according to the literature, it appears that the word bioethics has been referred to earlier in 1927 by German protestant, Fritz Jahr in his article "Bio-Ethik. Eine Umschau über dies ethischen Beziehungen des Menschen $\mathrm{Zu}$ Tier und Pflanze, which was later mentioned in a conference by Rolf Löther in 1997"[7]. After the discovery of his work in 1997, Fritz Jahr (18951953) has gradually acknowledged as the author of the term and concept of Bioethics [8]. The name of US political activist Sargent Shriver is also mentioned in the literature as a pioneer who used the term 'bioethics' in 1970 when they opened the Joseph and Rose Kennedy Institute for the Study of Human Reproduction and Bioethics at Georgetown University.

\section{Animal cloning}

Cloning is a process used to create a genetically identical replica of another cell, tissue, organ or an organism [9]. The replica is known as a clone that has the same genetic makeup as the original. Typically, there are three different types of cloning:

- Gene cloning: This process creates a duplicate set of genes or segments of DNA that can identify certain genetic abnormalities.

- Reproductive cloning: This process creates copies of the entire animal.

- Therapeutic cloning: This process creates embryonic stem cells which can be utilized for medical use.

Scientists have successfully cloned many animal species (Table:1) such as primates, dogs, and a host of endangered animal species. 
Table 1: List of cloned animals

\begin{tabular}{|c|c|c|c|}
\hline Sr. No. & Cloned animals & Year & First Citation \\
\hline 1 & Sea Urchins & 1885 & $\begin{array}{l}\text { Hans Adolf Eduard Driesch et } \\
\text { al. (1885) }\end{array}$ \\
\hline 2 & Salamanders & 1902 & Hans Spemann et al. (1902) \\
\hline 3 & Fish Cloned & 1952 & Tong Dizhou et al. (1963) \\
\hline 4 & Cloning of Frogs & 1958 & $\begin{array}{c}\text { Robert Briggs and Thomas } \\
\text { King et al. (1958) }\end{array}$ \\
\hline 5 & Rabbits & 1975 & Chesne et al. (2002) \\
\hline 6 & Cows & 1987 & Forsberg et al. (2002) \\
\hline 7 & Dolly the sheep's born & 1996 & Wilmut et al. (1997) \\
\hline 8 & $\begin{array}{l}\text { Monkeys; Transgenic } \\
\text { technology introduced }\end{array}$ & 1997 & Li Meng et al. (1997) \\
\hline 9 & Mice & 1998 & Wakayama et al. (1998) \\
\hline 10 & $\begin{array}{l}\text { Endangered Gaur and } \\
\text { interspecies surrogacy \& } \\
\text { therapeutic cloning } \\
\text { introduced }\end{array}$ & 2001 & Lanza et al (2000) \\
\hline 11 & Cat & 2001 & Shin et al. (2002) \\
\hline 12 & $\begin{array}{l}\text { Human Genome project } \\
\text { done - banteng, }\end{array}$ & 2003 & Sansinena et al. (2005) \\
\hline 13 & Deer & 2003 & $\begin{array}{c}\text { Texas A\&M announcement } \\
(2003)\end{array}$ \\
\hline 14 & Horse & 2003 & Galli et al. (2003a) \\
\hline 15 & Mule & 2003 & Woods et al. (2003) \\
\hline 16 & $\begin{array}{l}\text { UN adopts a ban on all } \\
\text { human cloning: dog, } \\
\text { Japanese team plans to } \\
\text { bring back mammoths }\end{array}$ & 2005 & Lee et al. (2005) \\
\hline 17 & Wolves & 2007 & Kim et al. (2007) \\
\hline 18 & Goat & 1999 & Keefer et al. (2002) \\
\hline 19 & Rat & 2002 & Zhou et al. (2003) \\
\hline 20 & Wildcat & 2003 & Gomez et al. (2003) \\
\hline 21 & Ferret & 2006 & Li Z et al. (2006b) \\
\hline 22 & Swamp Buffalo & 2006 & Suteevun et al. (2006) \\
\hline 23 & Pig & 2000 & Polejaeva et al. (2000) \\
\hline 24 & Mouflon Sheep & 2000 & Loi et al. (2001) \\
\hline
\end{tabular}

\section{Evolution of animal cloning}

There are a number of reports describing animal cloning in the past. In 1901, the nucleus of salamander from its embryonic cell was transferred to an enucleated cell. During the mid $19^{\text {th }}$ century, scientists were able to clone embryos in mammals and in 1962, the mature frog was developed by transferring the nucleus of intestinal cells of tadpoles into enucleated eggs [10]. Later in 1984, Sheep cloning from embryonic cells was attempted. In 1994, bovine cloning was tried from embryonic cells taken from another cow [9].

In 1995, the first successful animal cloning was made by Ian Wilmut et.al. at the Roslin Institute in Scotland; cloning two lambs viz. Megan and Morag. The lambs were cloned from cells taken from an early embryo. The same scientists cloned Dolly sheep one year later using somatic cells 
[11]. The Dolly sheep was created using mature cells of mammary glands from a mature sheep (Figure 1) [9]. In general, the success rate of animal cloning is quite low and ranges from 0.1 percent to 3 percent, which signifies that for every 1000 attempts, only 1 to 30 clones are made. A cloning project was launched by the Korean scientists to produce pigs with genetically altered hearts [12]. Various agricultural researchers produced different types of cloned animals with altered genes making their milk or meat healthier for consumers, further disease-resistant clones were also created to narrow down the environmental burden e.g. cows that are resistant to brucellosis were cloned by scientists at A\&M University Texas [13]. Now scientists are focussed on cloning goats so as to produce milk with less fat; featherless chicken to reduce the costs of poultry farming and pigs whose manure has very low phosphorus which helps to limit the environmental pollution [14].

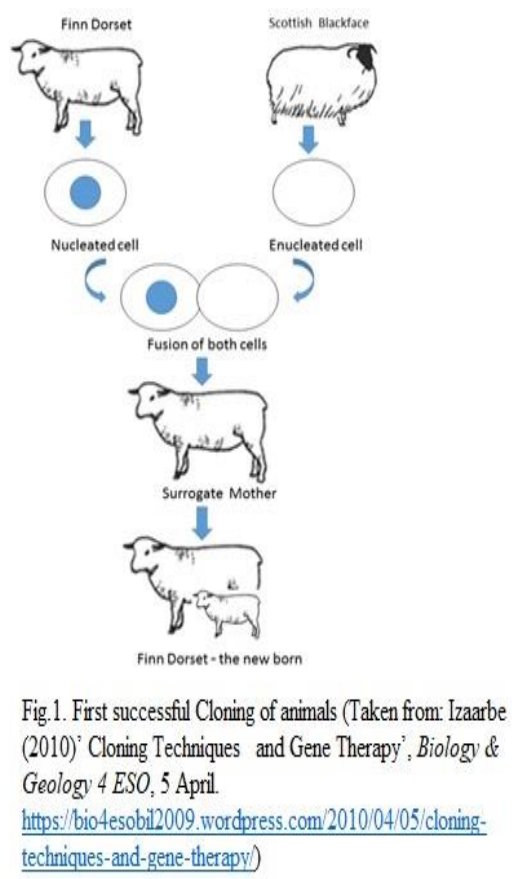

Figure 1: First successful cloning of animals

Many endangered or even extinct species may be restored soon by animal cloning. In 2001 Indian bison (a type of wild ox) which was on the verge of extinction was cloned but unfortunately died in the early stage of growth due to dysentery which is not related to the cloning process [15]. There are many on-going projects to restore various extinct species like Thylacine, Asian cheetah, and Wooly mammoth by cloning techniques [16]. One of the well-known and difficult cloning projects is the Missyplicity Project, in which they cloned a dog who had died, but three cloned puppies were born and delivered to the owner [17]. Later on, a project known as CopyCat was launched with an objective to clone the cats.

There have been a few public discussions on a number of ethical issues related to animal cloning projects. A number of surveys have been made in the past describing ethical issues in animal cloning. One such survey done by Gallup in 2005, (Figure.2.) describes the views of Americans suggesting animal cloning which seems to be is ethically wrong [18]. It is not clear from this survey whether it was a public decision or a public reaction? [11].

\section{Ethics of cloning}

Animal cloning may give rise to two different types of moral problems 1 . It may create some negative impacts on animals, human beings and the environment; 2 . It may disobey various important moral principles $[19,20]$. The negative impacts that occur to animals can be understood both narrowly and broadly. Narrowly understood negative impact includes pain \& suffering which are the most serious consequences experienced by animals during the cloning process. While the 
broadly understood negative impact on animals includes the adverse effect of cloning on other animals or threatened species.

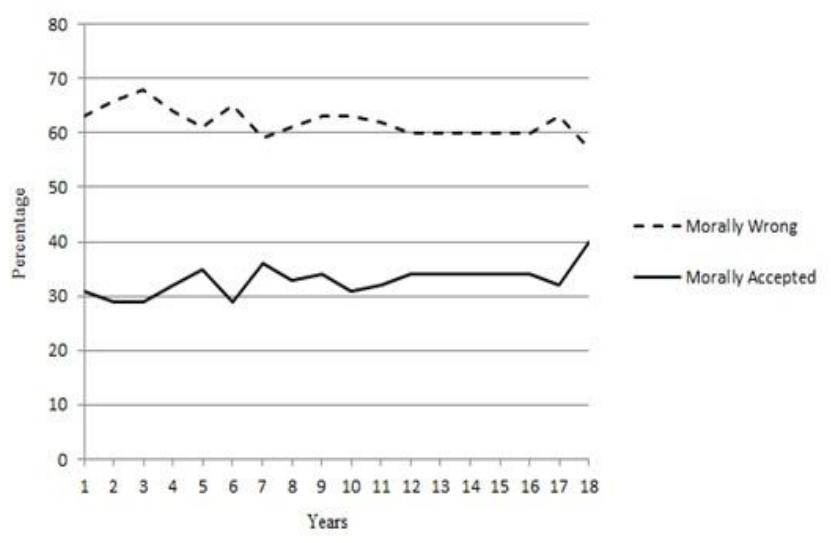

Fig.2: Graph showing the percentage of Americans for and against animal cloning (data taken from $\underline{\mathrm{Saad}} 2004$ ).

Figure 2: Percentage of Americans for and against cloning

Statistical data on the success rate of animal cloning procedures and the health of animals shows a gloomy view. A large number of literature citations have shown high rates of spontaneous abortion, premature death, stillbirth, genetic disorders, chronic illness in cloned animals, Due to the above mentioned problems the efficiency of animal cloning has drastically reduced to about 1$2 \%$ which means only 2 out of 100 embryos get successfully implanted in surrogate animals and become offspring $[21,22]$. Despite of their efficiency rates are at their best, the overwhelming majority of successful attempts failed to be fruitful.

Efficiency formula may be stated as:

Percent efficiency in animal cloning $=\frac{\text { Number of live offspring produced }}{\text { Total number of transferred embryos }} * 100$

\section{Risk to clone animals}

From the literature, the term "risk" is commonly used and has many different meanings. Risk is defined as a "chance or possibility of danger, loss, injury, etc." In relation to animal cloning, risk can be defined as a possibility to cause potential effects to cloned animals, surrogate dams and the environment. Risk assessment is the process of evaluating the possible risks arise due to animal cloning process.

The animals involved in animal cloning experiments are subjected to high risks adversely affecting them which includes abnormal placentation, pregnancy toxemia, and hydroallantois. In one study it was found that 5 out of 10 cloned pigs died between 3-130 days of age from sickness like chronic diarrhoea, congestive heart failure and decreased growth rate which results in a $50 \%$ mortality rate [23]. In another study also the case of early death of cloned mice has been reported [24]. Other findings in studies on calves show that there were 106 live births out of 2170 implanted embryos in which 24 died shortly after birth and 11 out of them showed severe physiological abnormalities like abdominal disorder, musculoskeletal abnormalities, Genito- urinal abnormalities, pulmonary failure, etc. A statistical analysis from multiple scientific studies with respect to the health status 
of clones revealed that $77 \%$ of cloned animals show no developmental abnormalities throughout the conduct. These adverse effects on animals due to cloning experiments led several international animal organizations to stand against it [25].

\section{Philosophical Views}

Several debates have held over a period of time to discuss the validity of animal cloning. It was concluded to ban the use of products from cloned animals and to prevent the use of animal cloning. For example, the U.S. Humane society which is an animal protection organization has requested to ban on products coming from cloned animals and their offspring. The vice president of this organization, Michael Appleby stated that the animal welfare problems that already exist will increase with the new biotechnological practices e.g., disease vulnerability. He argued: "Already animals are suffering from maladies at a rate unheard of before we applied biotechnology to the barnyard. It would be disastrously premature to put this technology into commercial practice" [26].

\section{Religious views}

Many religions have various guidelines or principles on doing things in the right way, on how should we live. Various philosophers proposed many ethical traditions or principles which can be classified into two categories 1) secular 2) spiritual [27].

Some ethical or moral theories are included in the secular division or western division, whereas religion comes under the spiritual division [27]. According to the Islamic religion research, one has to ultimately find the truth and to observe the signs of Allah's glory in order to understand natural phenomena and the hidden story behind the universe [28].

In the early Christian era, St. Augustine (AD 354 - 430) a theologian and Neoplatonic philosopher was highly influential. He mentioned that the percept "Thou shalt not kill" is not applicable to animals, because as they do not object and are unlike humans. According to him, God created an animal for the betterment of humans so people should also protect animals for their own uses.

\section{Use of cloned animals for food and health}

The impact of food production from cloned livestock arose many questions. One part of the question is ethics and the other part is science. The next question arises about the safety of such food to eat. However, in late October 2003, the US FDA stated that no evidence could be found against the safety of the food and milk derived from cloned animals [29]. But in another statement, they claimed that due to lack of sufficient information it was not possible to justify that cloned food was safe [30]. Finally, in 2008 after gathering the safety data from USDA the US FDA approved the use of cloned animals for their food and milk products [31].

The pain, sufferings, and difficulty that animals feel due to cloning procedures can be justified by their noble uses like curing humans and animal diseases or protecting threatened species. It should be permissible for this reasons because it is helpful in solving the pain of human being and other animals but it should not be permissible for the reasons like making animals more attractive for art purposes, for example, the deer's are cloned to get large antler and to make them more attractive to hunters or production of chimera to keep them as an art object [11].

\section{Other advantages and applications of animal cloning}

The advantages and applications of animal cloning are far beyond that of the ability of human thinking. Though some important applications of animal cloning can be (i) Recreation and replication of animals that are going to be extinct (ii) the possibility of selective breeding by cloning animals of desired characteristics. (iii) Generation of transgenic farm animals as animal models to study some human diseases [32]. (iv) Solving the issues of infertility by using some alternative approaches like IVF (In vitro fertilization) (v) improving the products from live stocks by cloning animals of better quality (vi) possibility in production of human therapeutics as well as xenograft tissues and organs with the help of somatic cloning, coupled with genetic modifications [33]. 


\section{Disadvantages of Cloning}

As the cloning is a new and uncommon procedure, its end results are still not clear in public mind due to which there have been internal and external conflicts. Internal conflicts include i) If the cloned animals are susceptible to face genetic problems and difficulty for survival in the long term, (ii) The more the cloned animals the more their extinction probability due to the changes in their genetic makeup which may increase the probability of death due to infections, as the clones may not have required immunity. (iii) the repeated cloning might result in the creation of monsters (iv) the creatures could be susceptible for the diseases such as cancer, (v) Premature aging: the clones are likely to grow older due to the premature aging e.g., if the donor is 40 years old then the newborn will also be 40 years old like it happened in the case of Dolly sheep [9].

\section{CONCLUSIONS}

Bioethicists are dealing with the various ethical issues with regard to law, medicine, biotechnology, life sciences, and philosophy. The controversy about the origin of the term Bioethics still remains unsolved between Fritz Jahr, Van Rensselaer Potter or Sargent Shriver [34, 35] but the name of Potter is prevailing. Though some of the applications in animal cloning are beneficial, however, most of them have adverse effects. The success rates in animal cloning are relatively low compared to expected outcomes and the efficiency of animal cloning process is quite less around 1-2\%. Also, the animals involved in cloning experiments may pose some potential risks to their life and to other animals. Bioethics is concerned with moral aspects, for the use of the animals in cloning experiments. It is a new and interdisciplinary field that helps in understanding and solving several ethical issues arising in the fields of food, medicinal, and life sciences. It may be considered as a better and useful way to protect threatened species and to recreate endangered species.

Though some organizations claim that the products derived from cloned livestock are harmful without having any supporting data in favour of their claim. In fact, in 2008 the US FDA has already approved the use of products from such live stocks like milk, meat...etc. for human consumption. Ethically justifiable conclusions depend on two kinds of judgments: factual (based on scientific evidence and theories), and ethical (based on the best available moral philosophy theories) one can say that the problems in animal cloning prevail over their benefits, requiring bioethical controls.

\section{REFERENCES}

1. Sodeke SO. Tuskegee University experience challenges conventional wisdom: is integrative bioethics practice the new ethics for the public's health?. J Health Care Poor 2012;23(4):15.

2. Twine R. Animals as biotechnology: ethics, sustainability and critical animal studies. Routledge; 2010.

3. Railton, D. 'What are stem cells and why are they important?'. Medical News Today. 2019 Feb 8. Available from https://www.medicalnewstoday.com/articles/200904.php

4. Jamieson D, editor. A companion to environmental philosophy. John Wiley \& Sons; 2008.

5. LaFort R, NRC KL, Tiraspolsky M. Implementing GM Technology in Order to Safeguard Endangered Species in Our Continuously Changing Environment. From umass.edu

6. Lopes M. LEGALIZAÇÃO DA MACONHA: DEBATE POLÍTICO, SOCIAL E JURÍDICO SOBRE SUA PERTINÊNCIA.

7. Muzur A, Rinčić I. Fritz Jahr (1895-1953): a life story of the" inventor" of bioethics and a tentative reconstruction of the chronology of the discovery of his work. Jahr 2011;2(4):385-94.

8. Rinčić I, Muzur A. Fritz Jahr: The invention of bioethics and beyond. Persp Biol Med 2011;54(4):550-6.

9. Nabavizadeh SL, Mehrabani D, Vahedi Z, Manafi F. Cloning: A Review on Bioethics, Legal, Jurisprudence and Regenerative Issues in Iran. World J Plast Surg 2016;5(3):213-8.

10. Atrak H. Human cloning and Kant's theory. Iran J Med Ethics Hist Med 2011;4(6):39-49.

11. Autumn F. Ethical issues in animal cloning. Persp Biol Med 2005;48(3):328-44.

12. Newswires DJ. South Korea to mass-produce pig organs for human transplants. June 12.

13. Phillips K. Disease-resistant bull cloned at Texas A\&M.

14. Thomas T. Cloned and genetically engineered animals. Humane Society of the United States. 
15. Gallagher J. Modifying life: A journey of discovery through the mysterious world of genetics. BBC. 2017 Sept $20 . \quad$ Available from http://www.bbc.co.uk/science/genes/gene_safari/clone_zone/extinct03.shtml.

16. AgBiotechNet. 2001. Cloning hopes for extinct species. 2003 . Available from http:www.agbiotechnet.com

17. Science Daily. Texas A\&M Clones First Cat. 2002 Feb 15. Available from https://www.sciencedaily.com/releases/2002/02/020215070841.htm

18. Saad L. The cultural landscape: What's morally acceptable. Gallup News Service. 2004;22:2-4.

19. Rollin BE. Animal research: a moral science. EMBO Reports 2007;8(6):521-5.

20. Singer P. Animal liberation: a new ethics for the treatment of animals. New York Review, New York. 1975.

21. Coleman A. Somatic cell nuclear transfer in mammals: Progress and application. Cloning 1999;1:185-200.

22. Paterson L. Somatic cell nuclear transfer (cloning) efficiency. 2003. Available from http://www.roslin.ac.uk/public/webtablesGR.pdf.

23. Carter DB, Lai L, Park KW, Samuel M, Lattimer JC, Jordan KR, Estes DM, Besch-Williford C, Prather RS. Phenotyping of transgenic cloned piglets. Cloning Stem Cells 2002;4(2):131-45.

24. Ogonuki N, Inoue K, Yamamoto Y, Noguchi Y, Tanemura K, Suzuki O, Nakayama H, Doi K, Ohtomo Y, Satoh M, Nishida A. Early death of mice cloned from somatic cells. Nat Genet 2002;30(3):253-9.

25. Cibelli JB, Campbell KH, Seidel GE, West MD, Lanza RP. The health profile of cloned animals. Nat Biotechnol 2002;20(1):13-9.

26. Humane Society of the United States (HSUS). HSUS asks the FDA to ban sales from cloned farm animals. 2003. Available from http://www.hsus.org/ace/15431.

27. Amin L. Modern biotechnology: Ethical issues, ethical principles and guidelines. MALIM 2009;10:3-16.

28. Amin LA, Jahi JM. Ethical Aspects of Genetically Modified Organisms Release into the Environment. Malaysian J Environ Manage 2004;5:99-111.

29. Neergaard L. FDA: Cloned animal meat appears safe. Washington Post. 2003.

30. Associated Press. FDA wants more data on cloned meat safety. Washington Post. 2003 Nov. 4. Available from http://washingtonpost.com/ac2/wp-dyn/A867-2003Nov4?language=printer.

31. Lenzer J. US Congress and European Research Council insist on open access to research results.

32. Smith LC, Bordignon V, Babkine M, Fecteau G, Keefer C. Benefits and problems with cloning animals. Can Veterinary J 2000;41(12):919.

33. Wells DN, Oback B, Laible G. Cloning livestock: a return to embryonic cells. Trends Biotechnol 2003;21(10):428-32.

34. Comstock G. Ethics and Genetically Modified Crops: A Brief for the Royal Commission on Genetic Modification of New Zealand.

35. Thomas S. Ethical and social considerations in commercial uses of food and fibber crops. In Proceedings of the First International Symposium on Ecological and Societal Aspects of Transgenic Plantations 2001 Jul 22 (pp. 92-98). 